\title{
Sexualidade e Gênero - As metáforas do biopoder
}

Rosana Ribeiro Patricio, UEFS

BOCAYUVA, Helena. Sexualidade e gênero no imaginário brasileiro: metáforas do biopoder. Rio de Janeiro: Revan, 2007, 192p.

O livro Sexualidade e gênero no imaginário brasileiro, de Helena Bocayuva, destina-se a quem já leu ou pretende ler alguns dos melhores romances brasileiros, do período romântico ao pré-modernismo, ou seja, de José de Alencar, Aluísio Azevedo e Lima Barreto, com algumas alusões à ficção de Machado de Assis. Seu ensaio traz à tona questões pouco discutidas nesses romances e dá ao leitor uma visão mais crítica para compreender certas situações ainda hoje presentes de forma residual na sociedade.

No período abordado pela autora, os romances brasileiros representam diversas cenas em família, focalizando-as através de premissas e conceitos que se originam no modelo de ordenação social européia, fenômeno que Michel Foucault denominou "biopoder". O filósofo francês explica e questiona os modelos elaborados pela sociedade européia, sobretudo a partir da França, para organizar a sociedade, ditar a formação das famílias e a educação das pessoas, numa visão higiênica e médico-sanitária da nação.

No Brasil, na virada do século XIX para o século XX, no contexto ainda marcado pelo escravismo, essas teses européias redundaram na adoção de uma política sanitária ostensiva, com as reformas urbanas, a vacinação em massa etc. Em suma, implantou-se aqui uma biopolítica, ou seja, aquilo que Joel Birman denomina "medicalização da sociedade", fato registrado em leis, documentos, fotos, projetos e também na literatura.

Helena Bocayuva identifica as metáforas do biopoder nos textos literários, analisando as relações entre sexualidade e gênero, conforme aparecem nos discursos narrativos da época, contribuição dos escritores em busca de uma estrutura ideal para a sociedade brasileira em formação. De fato, como mostra a ensaísta, os registros literários são ricos em cenas em família, em situações em que as personagens tomam atitudes e se comportam de uma forma ou de outra, de acordo com a educação recebida, - ou a alegada falta dela -, no lar e na vida social. Assim, é no âmbito das relações familiares, ou na precariedade dessas relações, que os escritores buscam as origens dos perfis psicológicos e da personalidade de homens e mulheres, descrevendo o seu caráter e julgando suas ações em sociedade.

Ao observar a estreita relação entre essa literatura e contexto social, a pesquisadora estabelece os pontos fundamentais que 
esclarecem as relações de biopoder na sociedade brasileira. No prefácio do livro, o psicanalista Joel Birman ressalta que "um dos méritos da pesquisa realizada por Helena Bocayuva foi o de indicar alguns dos impasses existentes para a implantação plena do biopoder no Brasil. Assim, examinando a produção literária brasileira, na segunda metade do século XIX e no início do século XX, indica a fragilidade da figura da mulher-mãe. A orfandade materna, com efeito, se impõe como problemática no imaginário romanesco de José de Alencar e Aluísio de Azevedo. A leitura acurada de Luciola (1862), Diva (1863), Senhora (1873) e de $O$ mulato (1891) indica isso com clareza". Considerando a literatura como representação de um contexto social, a ensaísta procura explicar, através de atitudes das personagens, os desdobramentos coletivos e os impactos da prática do biopoder. Joel Birman destaca ainda que "o outro mérito dessa construção, que nos foi proposto pela pesquisa de Helena Bocayuva, é o de inscrever a problemática da biopolítica no Brasil no registro do imaginário literário” (p. 23).

Através do ensaio de Bocayuva, observa-se que essas narrativas, emblemáticas na constituição do imaginário brasileiro, alimentaram a formação cultural da intelectualidade e ilustram a questão da sexualidade como metáfora para as relações sociais, no imaginário biopolítico.

Em Alencar, a estudiosa faz o seu recorte em Luciola, Diva e Senhora, destacando que "Lucíola encena aspectos importantes do biopoder. A cortesã serve de contraponto à mãe higiênica ou à honesta trabalhadora. $\mathrm{O}$ 'nervoso' está presente, remetendo ao paradigma da degeneração" (p. 41). Temos então pólos antitéticos de representação da mulher, estabelecendo uma prioridade para o modelo familiar, uma vez que o final de Lucíola não é feliz, mas trágico e ideologicamente higiênico, avalizando o discurso competente da medicina oitocentista, sempre pronta a explicar o 'nervoso', ou 'as crises de nervos' das personagens, pela falta de melhor formação familiar e educacional. Nesse capítulo, a estudiosa conclui que: "Decididamente, nos romances de Alencar aqui observados, o feminino não serve de metáfora para o lugar visto como inferior da sociedade" (p.94), pois os homens se colocariam à sombra das mulheres e as mulheres seriam personagens fortes. No entanto, deve-se lembrar que, ao final do romance Senhora, Aurélia se põe aos pés de Fernando Seixas, numa completa atitude de submissão, contrastando com todo o império e altivez anteriores da personagem.

Em Aluísio Azevedo, a pesquisadora aborda os romances O mulato (1881) e Casa de pensão (1884). No primeiro, discute os estereótipos aplicados aos mestiços, ou seja, a falsidade, a inconstância e a leviandade, que, na narrativa, é simulada por dois personagens, Manuel Pescada e o cônego Diogo. A Ana Rosa são atribuídos ataques de "deus-nos-acuda", ou "nervoso" e até mais de um ato histérico, com a descrição dos ataques. No segundo romance, o protagonista, portador de sífilis, é um alvo rentável para os saberes médicos, com a confluência do saber jurídico. Aliás, o romance é baseado num crime dito de honra, fato ocorrido em novembro de 1876, um homicídio conhecido como "Questão Capistrano”. Assim, Capistrano Cunha, amigo de Antônio, mantém relações com Júlia, irmã de Antônio, estes últimos filhos de uma professora de piano que alugava quartos. Capistrano recusa-se a casar por obrigação. Levado à justiça e inocentado, e logo é assassinado por Antônio, o irmão ofendido, que 
cumpre o papel de homem que "lava a honra dessa familia." Como se observa, além do discurso médico, ocorre o entrelaçamento da questão jurídica.

Em Lima Barreto, a ensaísta analisa o caso de sedução da jovem Clara dos Anjos por Cassi Jones, as investidas e fugas do sedutor, que fica impune diante de uma família fraca e incapaz de se impor socialmente. Trata-se de outra situação que envolve a sexualidade, eixo forte do biopoder e suporte da família. No episódio, a fragilidade da figura materna, Dona Engrácia, é destacada pelo narrador, assim como a impotência do pater famílias diante da trajetória banalizada do jovem que seduz, engravida e abandona a moça, dentro da tradição de irresponsabilidade tolerada na geração de filhos não reconhecidos, e tecnicamente considerados "ilegítimos".

O ensaio de Helena Bocayuva vem, em boa hora, preecher uma lacuna nos estudos da literatura brasileira da virada do século XIX para o século XX. O estudo aparece pari passo com um fenômeno inquestionável no cenário brasileiro atual. Recentemente, o IBGE divulgou uma estatística que confirma a tendência ao aumento de lares chefiados por mulheres sós no Brasil. A forma como a sociedade tem visto a mulher, mães e filhas, e suas relações na cena familiar, tem muito a ver com um imaginário que precisa ser analisado criticamente, a partir dos documentos e, sobretudo, através das representações literárias. De fato, muito do que se afigura hoje, tem explicação no pas- sado, nas hierarquias, no poder do patriarcado, na medicina oitocentista que aplicava conceitos e estipulava normas de comportamento social. Essas representações são encontradas na literatura, através de descrições, questionamentos ou até mesmo denúncias de certas práticas sociais aplicadas às mulheres, à guisa de uma educação "apropriadamente" feminina.

O livro insere-se nos estudos de saúde coletiva, no âmbito da medicina social, e responde ao crescente interesse pela participação feminina na sociedade. Personagens de ontem e de hoje, elas são mulheres solteiras, viúvas ou separadas, sobretudo mães, donas de casa, profissionais, que trabalham em turnos integrais, muitas vezes com pouco tempo para seu descanso e lazer. Como compreender esse atual estado de coisas para as mulheres, sejam elas de classes sociais distintas, casadas ou não, mães ou não, senão buscando nos registros do passado as origens desses problemas?

Em seu ensaio, Bocayuva consegue extrair dos romances os elos explicativos do passado que nos remetem a uma melhor compreensão da situação atual de certas questões relativas à família. Nesse sentido, são significativas as palavras finais da ensaísta, sobre os livros estudados: "São narrativas que destacam a falta de normas e de mães, metáforas que fundem hoje discursos sobre impunidade ou a falta de pai e lei. Falácias ou fábulas produzidas pelo imaginário de um país onde a maioria dos domicílios é chefiada por mulheres sós". 